\title{
PENDAPAT AUDITOR ATAS LAPORAN KEUANGAN UNTUK PERUSAHAAN YANG TERDAFTAR DI BURSA EFEK JAKARTA
}

\author{
Antonius Herusetya ${ }^{1}$
}

\begin{abstract}
Reports are essentials to audit and assurance engagements because they communicate the result of auditor's findings. The reason for this research is to study what types of the audit report has been issued for listed public companies in Bursa Efek Jakarta (BEJ). Audited reports from 106 sample companies are examined. Our findings reveal that most of the audit opinion among listed companies in Indonesia is unqualifed opinion (51.89\%), followed by unqualified opinion with explanatory paragraph (39.79\%), qualified opinion (7.55\%), and disclaimer opinion (3.77\%). Each audit opinion has its own condition that varies among many companies.
\end{abstract}

Keywords: auditor, comparative financial report, public company, Jakarta Stock Exchange

\section{ABSTRAK}

Laporan sangat penting bagi audit dan perjanjian asuransi karena laporan tersebut mengkomunikasikan hasil yang ditemukan oleh auditor. Penelitian ini bertujuan untuk mempelajari tipe laporan audit yang dikeluarkan dalam daftar perusahaan publik di Bursa Efek Jakarta (BEJ). Laporan audit ini mengambil 106 sampel perusahaan untuk dianalisis. Dalam penelitian ditemukan bahwa kebanyakan dari audit opinion yang terdapat dalam daftar perusahaan di Indonesia adalah unqualifed opinion (51.89\%), diikuti dengan unqualified opinion dengan paragraf penjelasan (39.79\%), qualified opinion (7.55\%), dan disclaimer opinion (3.77\%). Setiap audit opinion memiliki persyaratan tersendiri yang bervariasi dalam setiap perusahaan.

Kata kunci: auditor, laporan keuangan komparatif, perusahaan publik, Bursa Efek Jakarta

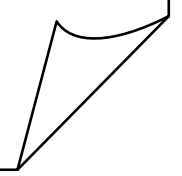

\footnotetext{
${ }^{1}$ Jurusan Akuntansi UPH Business School, Lippo Karawaci, Tangerang 15811 aherusetya@yahoo.com
} 


\section{PENDAHULUAN}

Laporan auditor atas laporan keuangan auditan atau audit report menjadi penting dalam perikatan audit atas laporan keuangan karena audit report mengkomunikasikan hasil temuan auditor dan berisi pendapat apakah laporan keuangan pihak ketiga yang diaudit telah disajikan secara wajar sesuai dengan prinsip akuntansi yang berlaku umum. Pengguna laporan keuangan, khususnya pemangku kepentingan di luar perusahaan akan bergantung pada pendapat auditor yang telah memberikan kepastian yang memadai (reasonable assurance) sehubungan dengan laporan keuangan perusahaan. Pemahaman akan jenis audit report serta penyebab atau kondisi yang menyebabkan dikeluarkannya jenis pendapat tertentu oleh kantor akuntan publik akan memberikan wawasan bagi pengguna laporan keuangan mengenai keandalan dari informasi yang terkandung laporan keuangan sebagai dasar pengambilan keputusan.

Audit report merupakan hasil akhir daripada seluruh proses audit atas laporan keuangan yang dihasilkan oleh kantor akuntan publik. Pada prinsipnya, terdapat dua kelompok jenis pendapat auditor, yaitu pertama, laporan auditor dengan pendapat wajar tanpa pengecualian, yang terbagi dalam: Pendapat wajar tanpa pengecualian dengan bentuk baku (unqualified opinion) dan Pendapat wajar tanpa pengecualian dengan paragraf penjelasan (unqualified opinion with modified wording or explanatory paragraph). Kelompok kedua adalah jenis pendapat yang menyimpang dari pendapat wajar tanpa pengecualian, yaitu Pendapat wajar dengan pengecualian (qualified opinion), Laporan auditor tanpa pendapat (disclaimer opinion), dan Pendapat tidak wajar (adverse opinion) (Messier, et al. 2006, Arens, et al. 2006).

Laporan auditor bentuk baku dengan pendapat wajar tanpa pengecualian hanya dapat diterbitkan bila laporan keuangan telah disusun sesuai dengan prinsip akuntansi yang berlaku umum dalam segala hal yang bersifat material. Laporan auditor ini memiliki bentuk baku dalam penyajian kalimat maupun jumlah paragraf dalam laporannya (PSA No. 29, par. 08). Dalam kondisi tertentu, auditor dapat menyatakan pendapat wajar tanpa pengecualian atas salah satu unsur laporan keuangan dan menyatakan pendapat wajar dengan pengecualian atau jenis pendapat lainnya apabila keadaan mengharuskan demikian (PSA No. 29 par. 05).

Perbedaaan audit report bentuk baku tersebut dengan jenis pendapat wajar tanpa pengecualian dengan paragraf penjelasan adalah bila terdapat kondisi sebagai berikut, yaitu karena adanya pendapat auditor sebagian didasarkan atas laporan auditor independen lain, laporan keuangan disajikan menyimpang dari prinsip akuntansi yang dikeluarkan oleh IAI, adanya kesangsian atas kelangsungan hidup entitas, terdapat perubahan material dalam penerapan prinsip akuntansi dengan periode sebelumnya, keadaan tertentu yang berhubungan dengan laporan auditor atas laporan keuangan komparatif, dan paragraf penjelasan untuk menekankan suatu hal tentang laporan keuangan (PSA No. 29 par. 11). 
Pendapat auditor atas laporan keuangan komparatif memiliki konsekuensi bagi auditor untuk memutahirkan laporannya atas laporan keuangan secara individu untuk satu atau beberapa periode yang lalu yang disajikan dalam bentuk komparatif dengan laporan keuangan periode sekarang (PSA No 29 par. 65). Dalam laporan auditor ini dimungkinkan juga terdapatnya perbedaan jenis pendapat auditor atas kedua laporan keuangan yang diaudit, misalnya pada tahun berjalan diberikan pendapat tanpa pengecualian, namun tahun sebelumnya memiliki pendapat dengan pengecualian.

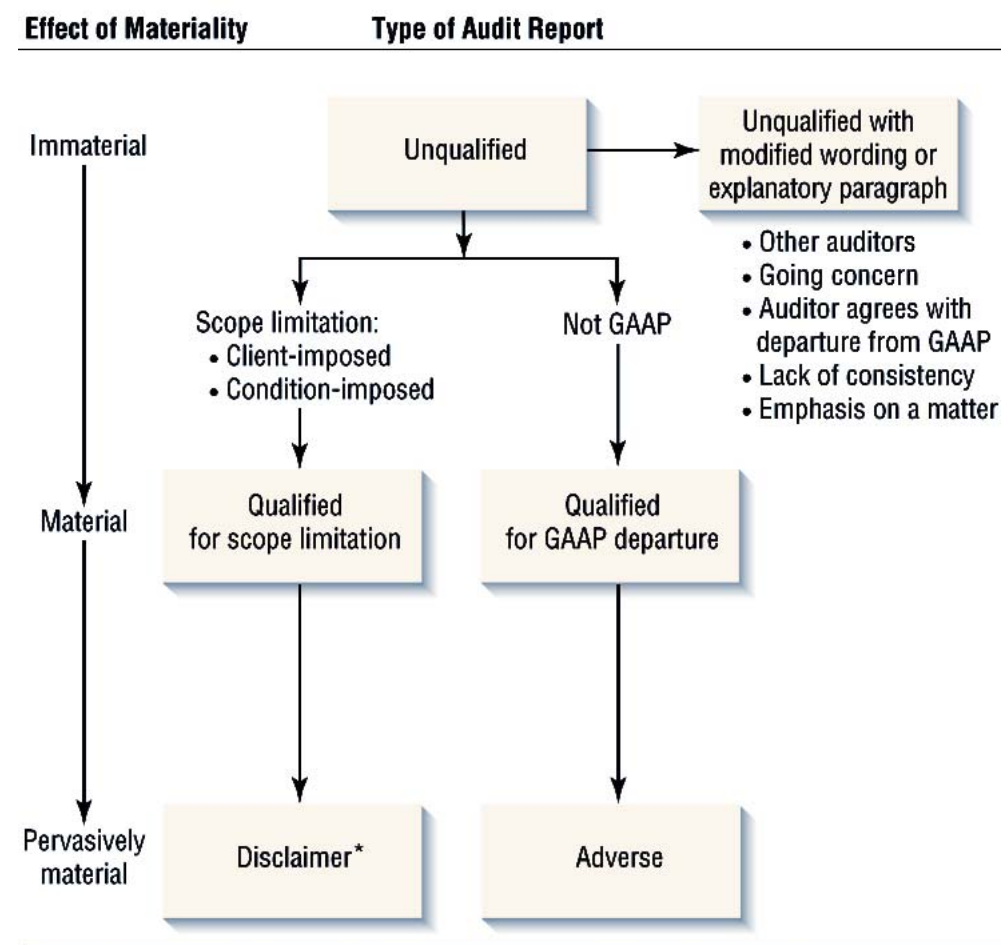

*An auditor will also issue a disclaimer for a lack of independence and, in some cases, for substantial doubt about the entity's ability to continue as a going concern.

Sumber: Messier, et al 2006

Gambar 1 Jenis Pendapat Auditor 


\section{METODE PENELITIAN}

Penelitian ini merupakan penelitian deskriptif menggunakan content analysis terhadap 106 laporan auditor independen untuk perusahaan publik yang terdaftar di Bursa Efek Jakarta (BEJ). Jumlah populasi dari perusahaan publik yang terdaftar di BEJ pada akhir tahun 2005 adalah 347 perusahaan.

Seluruh perusahaan publik tersebut telah dikelompokkan dalam 9 (sembilan) katagori industri utama tiap industri utama memiliki subindustrinya. Dalam penelitian deskriptif, menurut Gay \& Diehl (1992), besarnya ukuran uji petik (sample) minimal agar layak untuk mewakili kondisi dari suatu populasi adalah sebesar 10 persen. Dalam penelitian ini, penulis menentukan besarnya uji petik sebesar 30,55 persen atau sebanyak 106 laporan auditor dengan laporan keuangan komparatif tahun 2005 dan 2004 agar dapat lebih menyakinkan bagaimana profil pendapat auditor independen atas laporan keuangan yang diaudit tersebut.

Metode pemilihan uji petik adalah berdasarkan convenience sampling (Sekarang 2003) tanpa memandang jenis industri utama maupun subindustri utama, dengan alasan data yang dikumpulkan adalah semata-mata berdasarkan audit report atas laporan keuangan komparatif Tahun 2005 dan 2004 yang diperoleh baik melalui internet, maupun laporan tahunan perusahaan yang bersangkutan pada PT Bursa Efek Jakarta. Setelah dilakukan pemilihan uji petik, masing-masing audit report yang dipilih dapat dikelompokkan kembali menurut industri utamanya sebagaimana ter lihat pada Tabel 1.

Tabel 1 Profil Populasi dan Uji Petik

\begin{tabular}{lcccc}
\hline \multirow{2}{*}{$\begin{array}{c}\text { Kategori Industri } \\
\text { Utama }\end{array}$} & \multicolumn{2}{c}{ Populasi } & \multicolumn{2}{c}{ Uji Petik } \\
\cline { 2 - 5 } & $\begin{array}{c}\text { Jumlah } \\
\text { Perusahaan }\end{array}$ & $\begin{array}{c}\text { Persentase } \\
\mathbf{( \% )}\end{array}$ & $\begin{array}{c}\text { Jumlah } \\
\text { Perusahaan }\end{array}$ & Persentase (\%) \\
\hline Pertanian & 11 & 3.17 & 1 & 0.94 \\
$\begin{array}{l}\text { Pertambangan } \\
\text { Industri Dasar dan }\end{array}$ & 10 & 2.88 & 2 & 1.89 \\
$\begin{array}{l}\text { Kimia } \\
\text { Aneka Industri }\end{array}$ & 53 & 15.27 & 17 & 16.04 \\
$\begin{array}{l}\text { Industri Barang } \\
\text { Konsumsi }\end{array}$ & 48 & 13.83 & 16 & 15.09 \\
$\begin{array}{l}\text { Properti dan Real Estate } \\
\text { Infrastruktur, Utilitas, }\end{array}$ & 37 & 10.66 & 12 & 11.32 \\
dan Transportasi & 20 & 10.66 & 17 & 16.04 \\
$\begin{array}{l}\text { Keuangan } \\
\text { Perdagangan, Jasa, dan }\end{array}$ & 65 & 5.76 & 5 & 4.72 \\
Investasi & 66 & 18.73 & 16 & 15.09 \\
\hline \multicolumn{1}{c}{ Total } & 19.02 & 20 & 18.87 \\
\hline
\end{tabular}




\section{HASIL PENELITIAN DAN PEMBAHASAN}

\section{Hasil Analisis Pendapat Auditor}

Hasil penelitian uji petik terhadap isi 106 laporan akuntan publik untuk laporan keuangan komparatif tahun 2005 dan 2004 menunjukkan bahwa untuk tahun audit 2005, terdapat 55 laporan auditor (51,89 persen) dengan pendapat wajar tanpa pengecualian dengan bentuk baku dan terdapat 39 laporan auditor (36,79 persen) dengan pendapat wajar dengan paragraf penjelasan. Dengan perkataan lain, terdapat 94 laporan auditor (88,68 persen) dengan katagori pendapat wajar tanpa pengecualian. Sisanya adalah 8 laporan auditor (7,55 persen) dengan pendapat wajar dengan pengecualian dan 4 laporan auditor (3,77 persen) tanpa pendapat. Tidak ditemukan adanya pendapat tidak wajar dalam jumlah uji petik yang diambil.

\section{Pendapat Wajar Tanpa Pengecualian (Unqualified Opinion)}

Pendapat wajar tanpa pengecualian berarti laporan keuangan perusahaan publik tersebut telah disusun secara wajar (bebas dari salah saji secara material) sesuai dengan prinsip akuntansi yang berlaku umum di Indonesia. Dari jenis pendapat wajar tanpa pengecualian bentuk baku tahun 2005 tersebut diatas ada 94,55 persen (52 pendapat auditor) memiliki pendapat yang sama dengan tahun sebelumnya dan ada 5,45 persen memiliki pendapat yang berbeda, yakni 3 (tiga) pendapat wajar tanpa pengecualian dengan paragraf penjelasan mengenai pendapat auditor pendahulu yang tidak disajikan.

Tabel 2 Jenis Pendapat Auditor terhadap Laporan Keuangan Komparatif

\begin{tabular}{|c|c|c|c|c|c|c|}
\hline No & Jenis Opini 2005 & $\mathbf{J m l}$ & $\%$ & Jenis Opini 2004 & $\mathbf{J m l}$ & $\%$ \\
\hline \multirow[t]{2}{*}{1} & \multirow{2}{*}{$\begin{array}{l}\text { Pendapat Wajar Tanpa } \\
\text { Pengecualian }\end{array}$} & \multirow[t]{2}{*}{55} & \multirow[t]{2}{*}{51,89} & Sama Dengan Tahun 2005 & 52 & 94,55 \\
\hline & & & & Berbeda & 3 & 5,45 \\
\hline \multirow[t]{2}{*}{2} & \multirow{2}{*}{$\begin{array}{l}\text { Pendapat Wajar Dengan } \\
\text { Paragraf Penjelasan }\end{array}$} & \multirow[t]{2}{*}{39} & \multirow[t]{2}{*}{36,79} & Sama Dengan Tahun 2005 & 36 & 92,31 \\
\hline & & & & Berbeda & 3 & 7,69 \\
\hline \multirow[t]{2}{*}{3} & \multirow{2}{*}{$\begin{array}{l}\text { Pendapat Dengan } \\
\text { Pengecualian }\end{array}$} & \multirow[t]{2}{*}{8} & \multirow[t]{2}{*}{7,55} & Sama Dengan Tahun 2005 & 7 & 87,50 \\
\hline & & & & Berbeda & 1 & 12,50 \\
\hline \multirow[t]{3}{*}{4} & \multirow{2}{*}{$\begin{array}{l}\text { Laporan Audit Tanpa } \\
\text { Pendapat }\end{array}$} & \multirow[t]{2}{*}{4} & \multirow[t]{2}{*}{3,77} & Sama Dengan Tahun 2005 & 1 & 25,00 \\
\hline & & & & Berbeda & 3 & 75,00 \\
\hline & Jumlah & 106 & 100 & & 106 & \\
\hline
\end{tabular}




\section{Pendapat Wajar Tanpa Pengecualian dengan Paragraf Penjelasan}

Pendapat wajar dengan paragraf penjelasan untuk tahun 2005 yang memiliki pendapat yang sama dengan tahun sebelumnya ada 92,31 persen atau 36 laporan auditor dan 7,69 persen atau 3 laporan auditor memiliki pendapat yang berbeda dengan tahun sebelumnya. Rincian perbedaan pendapat akuntan tahun 2004 dengan tahun 2005 terdiri dari 1 (satu) laporan auditor dengan pendapat wajar dengan pengecualian dan 2 (dua) laporan auditor tanpa pendapat.

Pendapat wajar dengan paragraf penjelasan untuk laporan keuangan tahun 2005 umumnya disebabkan oleh karena ketidakpastian terhadap kelangsungan hidup, adanya perubahan prinsip akuntansi yang berlaku umum dengan tahun sebelumnya, sebagian pendapat auditor pendahulu, penjelasan atas pendapat auditor lain yang melakukan audit atas anak perusahaan, dan penjelasan auditor mengenai perubahan jenis pendapat dengan tahun sebelumnya. Kondisi yang menyebabkan timbulnya paragraf penjelasan tersebut diatas dapat terjadi lebih dari satu kondisi atau merupakan kombinasi dari beberapa keadaan tersebut sehingga memungkinkan adanya tambahan beberapa paragraf penjelasan.

Kondisi yang menyebabkan adanya paragraf penjelasan untuk jenis pendapat auditor pada tahun 2004 disebabkan oleh kondisi ketidakpastian akan kondisi ekonomi yang berpengaruh terhadap kelangsungan perusahaan dan selebihnya tidak diketahui penyebabnya mengingat sumber data yang diteliti adalah laporan auditor atas laporan keuangan komparatif 2005 dan 2004.

Bila dilihat pada sebaran kondisi yang memerlukan paragraf penjelasan dalam Tabel 3 maka hanya ada 21 laporan auditor dengan 1 (satu) kondisi yang memerlukan penjelasan dari 39 laporan auditor. Kondisi terbanyak menjelaskan mengenai keraguan auditor tentang kelangsungan hidup perusahaan (11 laporan auditor) dan masalah penerapan prinsip akuntansi yang tidak taat azas (6 laporan auditor). Laporan auditor lainnya berisi 2 (dua) atau lebih kondisi yang memerlukan paragraf penjelasan. Bila dilihat dari variabel terbanyak yang memerlukan paragraf penjelasan maka kondisi keraguraguan atas kelangsungan hidup perusahaanlah yang paling mendominasi, yakni ada 24 laporan auditor dari 39 laporan auditor. Adapun rincian sebaran dikeluarkannya jenis pendapat ini untuk tahun 2005 dapat dilihat pada Tabel 3. 
Tabel 3 Sebaran Pendapat Audit Wajar Tanpa Pengecualian dengan Paragraf Penjelasan Tahun Audit 2005

\begin{tabular}{lcc}
\hline & Frekuensi & Persentase \\
\hline Kelangsungan Hidup & $\mathbf{1 1}$ & $\mathbf{2 8}$ \\
Konsistensi & $\mathbf{6}$ & $\mathbf{1}$ \\
Sebagian Pendapat Auditor Lain & $\mathbf{1}$ & $\mathbf{1}$ \\
Penjelasan Pendapat Auditor Lain Atas Anak Perusahaan & $\mathbf{2}$ & $\mathbf{3}$ \\
Penekanan Masalah & $\mathbf{4}$ & $\mathbf{5}$ \\
Kelangsungan Hidup Dan Konsistensi & $\mathbf{3}$ & $\mathbf{1 0}$ \\
Kelangsungan Hidup Dan Pendapat Auditor Lan & $\mathbf{1}$ \\
Kelangsungan Hidup Dan Penjelasan Pendapat Tahun Sebelumnya & $\mathbf{8}$ \\
Kelangsungan Hidup Dan Penjelasan Pendapat Auditor Lain Atas Anak & $\mathbf{4}$ \\
Perusahan & $\mathbf{1}$ \\
Sebagian Pendapat Auditor Lain Dan Konsistensi & $\mathbf{1}$ \\
Penjelasan Pendapat Auditor Lain Atas Anak Perusahaan Dan Konsistensi & $\mathbf{1}$ \\
Sebagian Pendpat Auditor Lain, Kelangsungan Hidup Dan Konsistensi & $\mathbf{1 0}$ \\
Penjelsan Pendapat Auditor Lain Atas Anak Perusahaan, Kelansusungan & $\mathbf{2}$ \\
Hidup Dan Konsistensi & $\mathbf{2}$ \\
\hline
\end{tabular}

\section{Pendapat Wajar dengan Pengecualian (Qualified Opinion)}

Pendapat wajar dengan pengecualian dimana pendapat auditornya sama untuk laporan keuangan komparatif tahun 2005 dan 2004 adalah 42,86 persen (3 laporan auditor) disebabkan adanya pembatasan ruang lingkup secara material oleh keadaan dan 57,14 persen (4 laporan auditor) karena ketidaksesuaian dengan prinsip akuntansi yang berlaku umum di Indonesia. Pendapat wajar dengan pengecualian yang berbeda dengan tahun sebelumnya ada 1 (satu) laporan auditor yang disebabkan adanya pembatasan ruang lingkup oleh keadaan dengan pendapat wajar dengan pengecualian.

Berdasarkan Tabel 4 dapat disimpulkan bahwa pendapat wajar dengan pengecualian untuk kedua tahun audit tersebut yang disebabkan adanya pembatasan ruang lingkup audit berjumlah 4 laporan (50 persen) dan 4 laporan lainnya ( 50 persen) adalah karena terdapatnya pembatasan ruang lingkup audit oleh keadaan. Dari seluruh laporan auditor tahun 2005 terdapat 62,50 persen laporan keuangan atau laporan keuangan anak perusahaannya diaudit oleh auditor lain pada tahun sebelumnya. 
Tabel 4 Penyebab Dikeluarkannya Pendapat Wajar dengan Pengecualian

\begin{tabular}{lccc}
\hline \multirow{2}{*}{$\begin{array}{c}\text { Jenis Pendapat Auditor } \\
\text { Tahun 2005 }\end{array}$} & \multicolumn{2}{c}{ Penyebab } & Jumlah \\
\cline { 2 - 3 } & $\begin{array}{c}\text { Pembatasan Ruang Lingkup } \\
\text { Audit }\end{array}$ & Tidak Mematuhi PABU & \\
\hline Sama & 3 & 4 & 7 \\
Berbeda & 1 & 0 & 1 \\
Jumlah & 4 & 4 & 8 \\
\hline
\end{tabular}

\section{Laporan Auditor Tanpa Pendapat (Disclaimer Opinion)}

Laporan akuntan publik tanpa pendapat, baik untuk tahun audit 2005 dan 2004 adalah sebesar 75 persen disebabkan adanya pembatasan ruang lingkup audit yang sangat signifikan sedangkan 25 persen adalah laporan audit yang berbeda dengan tahun sebelumnya. Laporan auditor tanpa pendapat diberikan apabila terdapat keadaan dimana auditor tidak memungkinkan untuk mengumpulkan bukti audit yang cukup dan kompeten yang nilainya sangat material, dan terdapat ketidakpastian atas kelangsung hidup perusahaan dimasa yang akan datang.

Bila diteliti lebih lanjut, pengecualian tersebut terjadi karena adanya ketidakpastian yang sigifikan atas penyelesaian pinjaman utang jangka panjang, sewa guna usaha, serta beberapa pinjaman sindikasi bank dan lembaga keuangan luar negeri, perusahaan dan anak perusahaan mengalami kerugian berturut-turut dan defisiensi modal, tidak memungkinkannya auditor untuk melakukan konfirmasi atau mendapatkan jawaban konfirmasi atas piutang usaha, piutang hubungan istimewa, hutang usaha, wesel bayar terjamin dan tidak terjamin, dan account- account lainnya yang jumlahnya sangat material.

Keputusan auditor dalam memberikan jenis laporan tanpa pendapat sesuai dengan PSA 29 par. 23 dan PSA 30 par. 11 yang menyatakan bahwa dampak yang mungkin timbul menyangkut banyak pos laporan keuangan dan auditor menyangsikan kemampuan entitas dalam mempertahankan kelangsungan hidupnya. Laporan auditor dengan pendapat yang berbeda dengan tahun sebelumnya disebabkan oleh karena adanya pembatasan ruang lingkup oleh keadaan.

\section{Paragraf dalam Laporan Auditor}

Hasil evaluasi terhadap isi laporan auditor menunjukkan adanya variasi dalam jumlah paragraf dari masing-masing jenis pendapat sebagaimana yang terdapat dalam Tabel 5, kecuali untuk jenis pendapat wajar tanpa pengecualian. Pada pendapat wajar tanpa pengecualian, bentuk baku ini memiliki jumlah paragraf sebanyak 3 (tiga), yaitu paragraf pendahuluan, paragraf ruang lingkup, dan paragraf pendapat. Pada jenis pendapat yang lain bervariasi sesuai dengan kondisi yang memerlukan satu atau lebih paragraf penjelasan. 
Tabel 5 Jumlah Paragraf Laporan Auditor

\begin{tabular}{lc}
\hline \multicolumn{1}{c}{ Jenis Pendapat auditor } & Jumlah Paragraf \\
\hline Pendapat Wajar Tanpa Pengecualian & 3 \\
Pendapat Wajar Tanpa Pengecualian Dengan Paragraf Penjelasan & $4-7$ \\
Pendapat Wajar Dengan Pengecualian & $5-8$ \\
Laporan Auditor Tanpa Pendapat & $5-9$ \\
\hline
\end{tabular}

\section{Profil Kantor Akuntan Publik}

Sebagian besar hasil penelitian ini menemukan bahwa 39,62 persen laporan keuangan perusahaan publik yang terdaftar di BEJ pada tahun 2005 telah diaudit oleh kantor akuntan publik lokal yang berafiliasi dengan KAP "the big four" sedangkan lainnya adalah sebesar 10,38 persen merupakan kantor akuntan publik internasional dengan katagori nasional (Arens, et al. 2006), 24,52 persen merupakan bentuk kerja sama dengan kantor akuntan publik internasional lainnya dan sisanya sebesar 25,47 persen merupakan KAP lokal Indonesia. Kantor akuntan the big four terbanyak dalam melakukan audit laporan keuangan tahun 2005 yang dijadikan uji petik adalah Ernst \& Young, yaitu sebanyak 16,98 persen, kedua adalah Deloitte \& Touche 12,26 persen, dan sisanya 10,30 persen diaudit oleh PWC dan KPMG.

Tabel 6 Profil Kantor Akuntan Publik

\begin{tabular}{llcc}
\hline Katagori KAP & & \multicolumn{2}{c}{$\begin{array}{c}\text { Jumlah } \\
\text { Persentase } \\
(\mathbf{\% )}\end{array}$} \\
\hline The Big Four & Ernst \& Young & 18 & 16,98 \\
& Deloitte \& Touche & 13 & 12,26 \\
& PWC & 7 & 6,60 \\
& KPMG & 4 & 3,77 \\
\hline Sub- total & 42 & 39,62 \\
\hline Kational & & 11 & 10,38 \\
Internasional & & 26 & 24,52 \\
Lainnya & & \multicolumn{2}{c}{} \\
Lokal & & 27 & 25,47 \\
\hline Jumlah & & 106 & 100,00 \\
\hline
\end{tabular}

Penda pat Auditor Atas ... (Antonius Herusetya) 


\section{PENUTUP}

Berdasarkan hasil penelitian dapat ditarik beberapa simpulan sebagai berikut. Pertama, dari penelitian yang dilakukan terhadap 106 laporan Auditor Independen atas laporan keuangan komparatif tahun 2005 dan 2004 perusahaan publik yang terdaftar di BEJ maka untuk tahun audit 2005 terdapat 51,89 persen laporan auditor dengan pendapat wajar tanpa pengecualian, 36,79 persen pendapat wajar tanpa pengecualian dengan paragraf penjelasan, 7,55 persen pendapat wajar dengan pengecualian, dan 3,77 persen adalah laporan auditor tanpa pendapat. Dalam penelitian ini tidak ditemukan adanya laporan auditor dengan pendapat tidak wajar.

Kedua, perusahaan publik yang dijadikan uji petik menggunakan jasa kantor akuntan publik baik yang tergolong " the big four" maupun " non big four", masingmasing sebesar 39,62 persen dan 60,38 persen. Ketiga, penyebab utama diterbitkannya laporan auditor pendapat wajar tanpa pengecualian dengan paragraf penjelasan sebagian besaar adalah karena masalah ketidakpastian terhadap kelangsungan hidup perusahaan, sisanya adalah karena masalah perubahan dalam penerapan prinsip akuntansi yang berlaku umum, sebagian pendapat auditor didasarkan atas pendapat auditor lain, maupun penjelasan pendapat auditor lain atas anak perusahaan.

Keempat, laporan auditor dengan pengecualian sebagian besar disebabkan tidak dipatuhinya prinsip akuntansi yang berlaku umum (PABU), yaitu sebesar 50 persen, sedangkan sisanya 50 persen adalah terdapatnya pembatasan ruang lingkup audit oleh karena oleh karena keadaan. Kelima, laporan auditor yang diterbitkan tanpa pendapat disebabkan oleh karena adanya pembatasan ruang lingkup yang sangat material maupun ketidakpastian atas kelangsungan hidup perusahaan yang sangat besar.

Saran untuk penelitian berikutnya adalah sebagai berikut. Pertama, perlu diteliti apakah terdapat dampak signifikan antara jenis opini dari auditor terhadap pembuatan keputusan investor dalam melakukan keputusan investasi. Kedua, perlunya diteliti lebih lanjut menggunakan laporan keuangan komparatif untuk beberapa tahun audit, apakah terdapat perubahan dalam jenis opini auditor, dan apakah penyebab utamanya. Hal itu dapat memberikan gambaran mengenai perkembangan profil opini auditor atas laporan keuangan perusahaan publik yang terdaftar di BEJ, khususnya bagi perusahaan yang telah lama listing di BEJ. 


\section{DAFTAR PUSTAKA}

Arens, A.A., Elder R.J., and Beasley M.S. 2006. Auditing and Assurance Services: An Integrated Approach. Eleventh Edition. New Jersey: Pearson Education, Inc.

Gay, L.R. and P.L. Diehl. 1992. Research Methods for Business and Management. New York: Machmillan Publishing Company.

Ikatan Akuntan Indonesia (IAI). 2001. Standar Profesional Akuntan Publik. Salemba Empat.

Messier W.F., S.M. Glover, and D.F. Prawitt. 2006. Auditing \& Assurance Services: A Systematic Approach. Fourth Edition. New York: McGraw Hill/Irwin.

Sekaran, U. 2003. Research Methods for Business- A Skill Building Approach. 4th Edition. John Wiley \& Sons, Inc. 